\title{
Why I . . love wild swimming
}

\section{Consultant geriatrician Clare Bostock talks to Jacqui Wise about the benefits of wild swimming for physical and mental health}

\section{Jacqui Wise}

London, UK

Wild swimming is an incredible way to simultaneously numb and heighten different senses, says Clare Bostock, a consultant geriatrician in Aberdeen.

"When you go wild swimming it feels like all your worries are washed away," says Bostock, who regularly swims in the North Sea where the temperature rarely gets above $13^{\circ} \mathrm{C}$. "The cold means you have to concentrate on controlling your breathing and settling into a swimming rhythm. It is a good way to completely empty your mind as you can't think about anything else."

When you get out of the water your skin is tingling and you get a mental buzz, enthuses Bostock, who admits she was initially nervous. "Regularly challenging myself in the sea means that I feel less fearful of other everyday challenges," she says.

Part of the joy comes from the beauty of swimming in the wild - whether it's in the sea, loch, or river. "In contrast to running or swimming in a pool, wild swimming is more about the experience than speed or distance. Every time is different so you don't get bored." Recently Bostock swam alongside seals. "I thought I'd be scared but I didn't feel threatened at all. It was an incredible experience."

Not all brushes with nature are so positive, however. Lion's mane jellyfish, which give nasty stings, can be a problem in the summer months. "Recently, I was swimming without gloves or boots and came across these jellyfish which have long tentacles and a body the size of a dustbin lid. It was utterly terrifying."

Growing up in Southend-on-Sea meant Bostock was used to swimming in the sea but she had never been a serious or competitive swimmer. When she first moved to Aberdeen in 2005 she didn't feel brave enough to venture into the North Sea's freezing waters.

Her first taste of wild swimming was in Knockburn loch-a purpose built loch about 40 minutes from her home-which is shallow and relatively warm. However, this hadn't prepared her for a triathlon in Loch Tay. "It was freezing cold and the water was so deep and dark. I was really out of my comfort zone and found it hard to control my breathing."

The experience didn't put her off and three years ago Bostock moved on from swimming in lochs to swimming in the North Sea in Aberdeen. She tries to go every week, swimming for about 30 minutes. In July she took part in her longest open water swimming challenge-a $5 \mathrm{~km}$ swim in Loch Morlich.

Wild swimming is low cost or free and certainly cheaper than a gym membership. Bostock swims in a wetsuit which cost around $£ 100$ ( $€ 116$; \$130) plus neoprene hat, gloves, and boots. Some people swim without wetsuits but that choice would depend on sea temperature and personal hardiness. Bostock feels swimming with a wetsuit lets her swim for longer as well as providing protection from jellyfish.

It's also important to think about the safety, she adds. "You should always have someone either watching you from the shore or swimming with you." Bostock swims with her husband and for reassurance keeps connected to him with a five metre bungee cord. She also uses a tow float - an inflatable bag that can be attached to her waist-to make her more visible to boats.

As a geriatrician, Bostock says her work has been particularly challenging in the past few years because of increasing demand. A lot of colleagues have had to take time off for stress or have left work altogether, she says. She would like to encourage more people to try wild swimming as a way to unwind. "It's impossible to think about work when swimming wild, especially when I can't feel my feet or see my hand in front of my face and my attention is focused on looking out for orca."

How to make the change:

- Get out your swimsuit and goggles. Consider a wetsuit

- Look for local wild swimming clubs. There are many Facebook groups dedicated to wild swimming and useful websites include www. outdoorswimmingsociety.com and outdoorswimmer.com

- Never swim alone and stay safe www.rlss.org.uk/open-water-swimmingsafety-guide

- Jump in! 